to see whether the new arrangements outlined in the early summer will restore its spirits or instead, by linking most public research support to the goal of "wealth-creation", will drive the iron deeper. So it is some comfort that Major, when in Japan, accepted that British policies on research have not always been wise. "Perhaps", he said at an exhibition of the technical wonders of modern Japan, "we have undervalued science and the application of science over the last 20 or 30 years."

Major's timing was immaculate. He was speaking on the eve of this year's conference of the British Labour Party, which began on Monday. On that occasion 30 years ago, the then Mr Harold Wilson (he is now a Lord) offered to transform the British economy by "white-hot technology" and went on to win a general election the following year. Unfortunately, that promise came to nothing. After the Wilson government had arranged for the building of a few aluminium smelters and the amalgamation of several small companies into larger groupings, the forced devaluation of sterling stopped it in its modernizing tracks. No succeeding politician has dared echo Wilson's recipe for prosperity.

Does Major's mild remark signal that the tide is turning? It is something that he should have acknowledged the possibility of error. Even if this was no more than the familiar loosening of tongues occasioned by foreign travel, it is more like a plus than a minus. And although the statement directs attention to the more distant past, there is little doubt that it will be read in Britain as an acknowledgement of recent error also. If the administration in the past decade had been that admirable, would this summer's new policy have been necessary? Indeed, the new doctrine is in some respects Wilsonian: research harnessed to "wealth-creation". We shall soon learn what that means.

Wisely, Major did not confuse his Japanese audience with too much detail, but in one respect he seemed to have it thoroughly flummoxed. Noting that the new British policy for research has as its centrepiece a scheme for deciding what kinds of projects to back by means of a "technological foresight initiative", he praised Japanese efforts of that kind, saying that Britain would follow suit. People in Japan are still wondering what Major meant. It is true that the Science and Technology Agency in Tokyo publishes an annual list of guesses about future discoveries (cancer cured by 2003, thermonuclear fusion economic by 2020 , that sort of thing), but that is not a recipe for research policy.

The best guess is that Major may have found among his briefing papers the legend that the Ministry of International Trade and Industry guides Japanese industry in directions determined by divination akin to the foresight technique that suddenly became fashionable in Whitehall a few months ago. The minister in charge of science, Mr William Waldegrave, is this week following Major to Japan in the hope of learning what foresight is before the time comes to practise it. The difficulty is that there is no such thing, but only what Adam Smith called the invisible hand, the often cruel censorship of manufacturers' ambitions by the forces engendered by freespending and prosperous consumers. Major should not be too disappointed when Waldegrave returns empty-handed.

\section{What's in a name?}

This week sees the appearance of yet another new section of Nature, under the somewhat old-fashioned title "Progress".

WHAT follows is an explanation of why this journal, which already has more named sections than can appear every week, should invent another. It is to be hoped that readers will not take this to be an attempt further to confuse them, but rather as a serious attempt to provide an account of progress (whence the name) in newly emergent fields of research. The purpose of articles appearing under this rubric is to draw attention to research topics only recently recognized as having an identity of their own and as potentially fruitful. They will ordinarily be written by practitioners in the field concerned, and will often (of necessity) describe research in which the authors have been personally concerned. For the convenience of readers, they will be squeezed within a maximum of four pages. They will supplement in an interesting way the cumulative record of discovery now provided by the standard weekly diet of original research and the commentary on it to be found under the heading "News and Views". They are not substitutes for formal reviews, but an alternative to them.

Every serious science journal, of course, takes it as given that one of the most valuable functions of the literature is to review emergent fields of research. By that means, the argument goes, students and others entering a field unfamiliar to them are provided with an account of what has gone before. By the same means, the research community is provided with a fair account of who did what, when and even why. And posterity (at least in the narrow sense of "people a few years from now") is provided with a means of understanding the origins of important avenues in research. All these are laudable objectives. Every active researcher applauds them. But most researchers are too busy to divert their energy and time to the compilation of a review of their own field. The need judiciously to apportion credit for intellectual innovation appears to be another impediment.

Those circumstances no doubt explain why the database of "reviews in preparation" patiently maintained by $\mathrm{Na}$ ture's Reviews Coordinator is, on the face of things, enough to keep Nature amply supplied with reviews for several years ahead. The most common annotation of the database is "WRITING"; many authors, it emerges, are still "WRITING" several years after agreeing to do so. Some forgiving hearts bleed for the pain thus caused. Others, harder and perhaps more cynical, take this phenomenon to be yet another sign of the gulf between hope and reality in most human affairs. When President Boris Yeltsin's hope of containing Russia's money supply is so regularly defeated by his and his people's wish that there should be plenty of money to spend, why should Nature (like all other journals) be dismayed that so great a proportion of promised reviews fails to materialize? It will be excellent if the rubric "Progress" seems to authors so much less forbidding that they are able to turn "WRITING" into something else more quickly. 